\title{
Upaya Peningkatan Peserta KB Aktif dalam rangka Pencapaian Target Renstra BKKBN 2015-2019 di Kabupaten Musi Rawas, Provinsi Sumatera Selatan
}

\author{
Sukmaniar ${ }^{1}$, Wahyu Saputra ${ }^{1}$, dan Dani Saputra² \\ ${ }^{1}$ Program Studi Pendidikan Geografi, Universitas PGRI Palembang, ${ }^{2}$ BKKBN Provinsi \\ Sumatera Selatan
}

Korespodensi: Sukmaniar (e-mail: umma.niar@ymail.com)

\begin{abstract}
Abstrak
Penelitian ini bertujuan untuk meningkatkan peserta KB aktif untuk mencapai target Renstra BKKBN 2015-2019 di Kabupaten Musi Rawas, Provinsi Sumatera Selatan. Penelitian ini menggunakan metode mixed methods. Temuan penelitian ini menunjukkan bahwa penyebab rendahnya peserta KB aktif adalah pemahaman bahwa banyak anak banyak rezeki, kekhawatiran merasa kesepian jika memiliki sedikit anak, masih berkeinginan mendapatkan anak dengan jenis kelamin yang berbeda, status pekerjaan suami, tidak memahami pentingnya $\mathrm{KB}$, tidak ada alat/cara KB yang sesuai dengan keinginan, dan tidak ada kegiatan/program KB. Upaya peningkatan jumlah peserta KB aktif dapat dilakukan dengan cara memberikan bantuan dana, pelatihan, manajemen sosialisasi, dan pelatihan alat KB pada PUS, kerja sama dengan pemangku kepentingan, pendekatan tokoh masyarakat, bantuan alat dan pemasangan kontrasepsi secara gratis, pemberian apreasiasi kepada pengguna $\mathrm{KB}$, melakukan monitoring dan evaluasi serta umpan balik, tinjauan kembali dari hasil monitoring dan evaluasi agar dapat diperbaiki pada program KB berikutnya demi tercapainya target Renstra BKKBN 2015-2019.
\end{abstract}

Kata kunci: peserta KB aktif, target Renstra BKKBN 2015-2019

\section{Efforts to Increase Active Participants of Family Planning in order to Achieve the Target of BKKBN Strategic Plan 2015-2019 in Musi Rawas Regency, South Sumatera Province}

\begin{abstract}
This study aims to increase active family planning participants in achieving the target of BKKBN Strategic Plan 2015-2019 in Musi Rawas Regency, South Sumatera Province. This research used the mixed methods. The findings of this study indicate that the cause of low active family planning participants are the understanding that more children more benefits, feeling of loneliness if they had fewer children, still expecting children of different sex, status of husband's occupation, lack of understanding of the importance of family planning, family planning methods and no family planning/programs. Efforts to increase the number of active family
\end{abstract}


planning participants can be done by providing funding, training, socialization management and training of family planning tools on couples of childbearing age, cooperation with stakeholders, community leaders approach, contraceptive tools and installation for free, appreciation given to family planning users, monitoring and evaluation as well as feedback, review of monitoring and evaluation results to be improved in the next family planning program to achieve the Target of BKKBN strategic plan 2015-2019.

Keywords: active family planning participants, BKKBN strategic plan targets 2015-2019

\section{Pendahuluan}

Pertumbuhan penduduk dapat dipengaruhi oleh beberapa aspek, misalnya kelahiran (Saputra \& Munandar 2017a), kematian, serta penduduk yang datang dan penduduk yang pergi dari wilayahnya (Soebyakto \& Saputra 2015; Soebyakto, Sukmaniar, \& Saputra 2016; Sukmaniar, Romli, \& Sari 2017). Sementara itu, pertumbuhan penduduk merupakan hal utama untuk menjalankan proses pembangunan nasional. Menurut BPS (2014: 15), salah satu masalah pada proses pembangunan adalah kependudukan yang mencakup, antara lain, jumlah, komposisi, dan distribusi penduduk. Oleh karena itu, diperlukan data mengenai penduduk menurut lokasi dan kesejahteraannya, seperti kesehatan, pendidikan, tempat tinggal, keamanan, dan fertilitas.

Salah satu wilayah dengan pertumbuhan penduduk yang signifikan adalah Provinsi Sumatera Selatan. Diketahui bahwa Provinsi Sumatera Selatan memiliki luas daerah 87.017,41 hektar dan secara geografis, terletak antara $1^{\circ}$ sampai $4^{\circ}$ Lintang Selatan dan antara $102^{\circ}$ sampai $106^{\circ}$ Bujur Timur. Provinsi Sumatera Selatan berbatasan dengan Provinsi Jambi di sebelah utara, dengan Provinsi Lampung di sebelah selatan, dengan Provinsi Bengkulu di sebelah barat, dan Provinsi Bangka Belitung di sebelah timur. Jumlah penduduk Sumatera Selatan berdasarkan data BPS tahun 2014 adalah 7.941.741 jiwa. Salah satu penyebab banyaknya jumlah penduduk di Provinsi Sumatera Selatan Selatan itu adalah faktor kelahiran (fertilitas).

Fertilitas yang tinggi dapat memengaruhi jumlah pertumbuhan penduduk. Menurut Mantra (2015: 145), fertilitas berarti terlepasnya bayi dari rahim seorang perempuan dengan adanya tanda-tanda kehidupan. Tingginya tingkat fertilitas dapat disebabkan oleh beberapa faktor, salah satunya adalah usia perkawinan pertama dan banyaknya pasangan usia subur (PUS). Usia perkawinan pertama seorang perempuan memengaruhi panjangnya masa melahirkan sehingga dapat meningkatkan jumlah fertilitas. Selanjutnya semakin banyaknya jumlah pasangan usia subur (PUS) akan memperbesar peluang banyaknya kelahiran. Oleh karena itu, banyaknya jumlah anak juga akan memperbesar tanggungan kepala rumah tangga untuk memenuhi kebutuhan material dan spiritual anggota rumah tangganya. Dengan demikian, pembatasan jumlah anak perlu diperhatikan agar tercapai keluarga yang sejahtera. Salah satu cara menekan laju pertumbuhan penduduk adalah melalui program Keluarga Berencana (BPS, 2014: 83). Keluarga Berencana (KB) merupakan salah satu upaya untuk menekan jumlah 
kelahiran yang akan terjadi. Jika jumlah kelahiran tinggi, maka kesejahteraan penduduk akan rendah yang disebabkan oleh semakin banyaknya beban yang akan ditanggung oleh kepala keluarga.

Penduduk dan Pemerintah Provinsi Sumatera Selatan telah menjalankan program KB untuk mengendalikan jumlah penduduk. Salah satu hal yang memengaruhi jumlah penduduk adalah kelahiran (Tarmizi, 2013: 27-28). Namun, program KB di Sumatera Selatan menghadapi masalah ketidakmerataan peserta KB aktif dan penggunaan alat kontrasepsi yang dapat meningkatkan pertumbuhan penduduk di Sumatera Selatan (Saputra and Munandar, 2017b). Wilayah dengan penggunaan alat kontrasepsi yang kurang optimal dibandingkan dengan wilayah kabupaten/ kota lainnya di Provinsi Sumatera Selatan adalah Kabupaten Musi Rawas dengan hanya 71,3 persen, sedangkan tampak bahwa 28,7 persen PUS belum menjadi peserta KB aktif.

Mengacu pada target Renstra BKKBN 2015-2019, diharapkan masyarakat mampu memperbaiki kehidupan ekonominya dan mudah mengakses segala informasi, khususnya akses PUS terhadap KB. Pencapaian Renstra BKKBN 2015-2019 berkaitan yang erat dengan Masyarakat Ekonomi ASEAN yang merupakan salah satu ujung tombak yang akan memudahkan penduduk menjalankan program KB dengan lebih baik lagi. Namun, optimalisasi peserta KB aktif harus terus ditingkatkan dengan melihat beberapa wilayah yang masih memiliki jumlah perserta KB aktif yang masih rendah di Sumatera Selatan.

Target Renstra BKKBN 2015-2019 dalam menurunkan jumlah fertiltas pada terdiri atas beberapa indikator, antara lain, adalah angka kelahiran total (TFR) per WUS (15-49 tahun), pemakaian kontrasepsi (CPR), kebutuhan ber-KB yang tidak terpenuhi (Unmeet Need), Peserta KB Aktif (PA) MKJP, dan tingkat putus pakai kontrasepsi. Indikatorindikator tersebut sebaiknya terdistribusi dengan baik di seluruh wilayah yang ada di Provinsi Sumatera Selatan. Berdasarkan data Sumsel dalam Angka Tahun 2017, indikator tidak terdistribusikannya dengan baik peserta KB aktif disebabkan oleh adanya kabupaten yang memiliki jumlah peserta KB aktif terendah, yaitu Kabupaten Musi Rawas.

Penyebab rendahnya jumlah peserta KB aktif dan upaya meningkatkan jumlah peserta KB aktif di Kabupaten Musi Rawas menjadi hal yang menarik untuk diteliti. Oleh karena itu, penelitian ini mengambil judul "Upaya Peningkatan Peserta KB Aktif dalam Upaya Pencapaian Target Renstra BKKBN 20152019 di Kabupaten Musi Rawas, Provinsi Sumatera Selatan". Tujuan penelitian ini adalah untuk mengidentifikasi penyebab rendahnya kesertaan KB di Kabupaten Musi Rawas dan merumuskan kebijakan untuk meningkatan kesertaan KB aktif di Kabupaten Musi Rawas.

\section{Metodologi}

Metode penelitian ini menggunakan mixed methods (metode campuran) dengan Sequential Explanatory Design. Sampel yang digunakan berjumlah 55 responden yang dianalisis dengan teknik pengukuran Skala Likert kemudian dianalisis dengan frekuensi (proporsi) pada program SPPS untuk melihat persentase setiap distribusi jawaban pada pendekatan kuantitatif serta kepada 9 informan, akan dilakukan wawancara secara mendalam dan dianalisis melalui reduksi data, penyajian data, dan kesimpulan data pada pendekatan kualitatif. 


\section{Pembahasan}

Penyebab Rendahnya Kesertaan KB di Kabupaten Musi Rawas

PUS yang ada di Kabupaten Musi Rawas memiliki banyak alasan yang menyebabkan mereka tidak ikut serta sebagai peserta KB aktif. Delapan alasan di antaranya adalah masih ingin mendapatkan anak dengan kelamin yang berbeda (65,5 persen), tidak memahami pentingnya KB (61,8 persen), status pekerjaan suami (60 persen), tidak ada kegiatan/program KB yang di wilayah tersebut (56,4 persen), tidak ada alat/cara KB yang sesuai dengan keinginan (54,5 persen), jumlah anak yang lebih dari 2 (52,7 persen), pemahaman bahwa banyak anak banyak

Tabel 1 Penyebab Rendahnya Kesertaan KB di Kabupaten Musi Rawas

\begin{tabular}{|c|c|c|c|c|}
\hline \multirow[b]{2}{*}{ No } & \multirow[b]{2}{*}{ Penyebab rendahnya kesertaan KB } & \multicolumn{3}{|c|}{ Pertanyaan } \\
\hline & & $\begin{array}{c}\text { Setuju } \\
\%\end{array}$ & $\begin{array}{c}\text { Netral } \\
\%\end{array}$ & $\begin{array}{c}\text { Tidak Setuju } \\
\% \\
\end{array}$ \\
\hline 1 & Jumlah anak lebih dari 2 orang anak & 52,7 & 7,3 & 40 \\
\hline 2 & $\begin{array}{l}\text { Pemahaman bahwa banyak anak } \\
\text { banyak rezeki }\end{array}$ & 45,5 & 12,7 & 41,8 \\
\hline 3 & Khawatir akan merasa kesepian & 45,5 & 10.9 & 43,6 \\
\hline 4 & $\begin{array}{l}\text { Masih berkeinginan mendapat anak } \\
\text { dengan jenis kelamin yang berbeda }\end{array}$ & 65,5 & 10,9 & 23,6 \\
\hline 5 & Usia suami yang masih muda & 30,9 & 9,1 & 60 \\
\hline 6 & Usia istri yang masih muda & 23,6 & 9,1 & 67,3 \\
\hline 7 & Usia pernikahan yang masih muda & 27,3 & 10,9 & 61,8 \\
\hline 8 & Status pekerjaan suami & 60 & 5,5 & 34,5 \\
\hline 9 & Status pekerjaan istri & 10,9 & 9,1 & 80 \\
\hline 10 & Faktor sosial & 12,7 & 18,2 & 69,1 \\
\hline 11 & Faktor agama & 16,4 & 10,9 & 72,7 \\
\hline 12 & Faktor budaya & 10,9 & 3,6 & 85,5 \\
\hline 13 & Sifat KB yang rumit & 16,4 & 12,7 & 70,9 \\
\hline 14 & Tidak memahami pentingnya KB & 61,8 & 5,5 & 32,7 \\
\hline 15 & Tidak tersedianya alat KB & 5,5 & 10,9 & 83,6 \\
\hline 16 & Tidak tersedianya petugas KB & 10,9 & 9,1 & 80 \\
\hline 17 & $\begin{array}{l}\text { Tidak ada alat/cara KB yang sesuai } \\
\text { keinginan }\end{array}$ & 54,5 & 16,4 & 29,1 \\
\hline 18 & $\begin{array}{l}\text { Jarak tempat pelayanan KB terlalu } \\
\text { jauh }\end{array}$ & 9,1 & 10,9 & 80 \\
\hline 19 & Tidak ada kegiatan/program KB & 56,4 & 7,3 & 36,3 \\
\hline 20 & Faktor ekonomi & 9,1 & 16,4 & 74,5 \\
\hline
\end{tabular}

Sumber: Hasil Perhitungan Data Penelitian 2017 
rezeki (45,5 persen), dan khawatir merasa kesepian jika memiliki sedikit anak (45,5 persen). Sementara itu, alasan agama yang merupakan salah satu alasan yang terendah hanya menunjukkan angka 16,4 persen saja. terkait dengan alasan tersebut, fakta yang ada di Kabupaten Musi Rawas menunjukkan persamaan dengan hasil penelitian dari Yeatman, dkk. (2008: 1873) yang menyatakan bahwa tidak ada hubungan antara agama dengan pemakaian kontrasepsi di perdesaaan Malawi. Untuk lebih detail tentang alasan penyebab rendahnya kesertaan $\mathrm{KB}$ di Kabupaten Musi Rawas yang lebih dominan, dapat dilihat pada Tabel 1.

PUS menginginkan anak yang berjenis kelamin berbeda merupakan alasan terpenting bagi mereka yang menyebabkan mereka tidak ikut serta menggunakan KB. Hal itu tampak dari persentasenya yang paling tinggi dibandingkan dengan alasan lainnya. Alasan dengan persentase tertinggi kedua adalah mereka tidak memahami pentingnya program KB.

\section{a. Jumlah Anak Lebih dari Dua}

PUS di wilayah Musi Rawas menyatakan pendapat dan persetujuan mereka bahwa mereka tetap menginginkan jumlah anak lebih daripada dua. PUS berharap di masa depan, anak-anaknya dapat membantu dan menemani mereka yang telah menurun kondisi kesehatannya. Memiliki jumlah anak yang banyak mampu memberikan kepuasan dan keyakinan bahwa mereka tidak akan terlantar di masa tuanya. Mereka berharap akan mendapatkan banyak pilihan untuk tinggal bersama anak yang memberikan kenyaman terbaik. Data di atas menunjukkan bahwa secara signifikan, 52,7 persen PUS menyetujui hal ini. Namun, terdapat 40 persen PUS di wilayah ini yang tidak setuju dengan alasan itu. Walaupun terdapat selisih 13 persen, dapat disimpulkan bahwa alasan ini tetap lebih menonjol di wilayah tersebut.

b. Pemahaman bahwa Banyak Anak Banyak Rezeki

Pemikiran yang masih ada di benak PUS bahwa anak akan memberikan rezeki bagi mereka karena mereka percaya setiap individu telah memiliki rezekinya masingmasing. Pemahaman ini memberikan kenyamanan tersendiri bahwa kehidupan mereka akan baik-baik saja jika mereka memiliki banyak anak. Dengan demikian, mereka memutuskan untuk tidak ikut serta menggunakan $\mathrm{KB}$.

Pemahaman bahwa banyak anak banyak rezeki adalah pemahaman lama yang masih ada sampai sekarang. Kebanyakan mereka mendapat pembenaran dengan mengatakan bahwa sampai saat ini anak-anaknya tetap dapat makan tanpa melihat nilai kualitas. Beberapa kasus menunjukkan bahwa keluarga yang mampu berhasil mendidik anaknya dengan baik, tetapi tidak sedikit pula yang tidak mampu meningkatkan kualitas anakanaknya karena putus sekolah akibat rendahnya kondisi ekonomi mereka. Berdasarkan data kuantitatif dan deskripsi kualitatif dapat dirincikan sebagai berikut. Terdapat 45 persen persentase PUS yang menyetujui bahwa banyak anak banyak rezeki, 42 persen PUS tidak setuju, dan yang ragu-ragu atau netral hanya berkisar 13 persen. Walaupun PUS yang menyetujui bahwa banyak anak banyak rezeki tampak mendominasi, proporsi perbedaan angkanya tidak terlalu jauh dengan PUS yang tidak setuju karena hanya berkisar 3 persen saja. 
c. Khawatir Merasa Kesepian

Dalam kehidupan berkeluarga, teman hidup tidak hanya berarti suami atau istri karena buah hati juga merupakan bagian terpenting dalam keluarga. Seorang ayah dan ibu akan merasa kesepian jika anak-anaknya telah menikah atau bekerja di wilayah lain. Oleh karena itu, mereka berusaha melahirkan banyak anak supaya di antara banyak anaknya, ada yang tetap memilih tinggal bersama mereka atau mereka dapat ikut tinggal di tempat anaknya tersebut. Alasan ini masih tetap menjadi pilihan para PUS untuk tidak melaksanakan program KB walaupun proporsi jawaban mereka yang setuju dan tidak setuju hanya selisih sedikit.

Ketika anak-anaknya pergi meninggalkan orang tuanya untuk bekerja, menikah, dan sebagainya, maka masih ada anak yang lainnya. Setidaknya masih ada yang mewarisi rumah dan ladang mereka karena biasanya selalu ada anak yang menurunkan warisan rumah dan ladang orang tuanya kepada anak-anak mereka. Oleh karena itu, mereka beranggapan bahwa jika memiliki jumlah anak yang sedikit, tidak ada yang akan menggantikan mereka dan membantu mereka jika telah tidak mampu melakukan pekerjaan yang membutuhkan tenaga yang besar. Data dari Tabel 1 menunjukkan bahwa selisih jawaban antara mereka bagi yang setuju dengan yang tidak setuju hanya 1 persen yang artinya merasakan kesepian bukanlah jawaban yang paling tepat sebagai penyebab mereka tidak menggunakan KB dan ini akan berdampak pada peningkatan jumlah peserta KB.

d. Masih Berkeinginan Mendapat Anak dengan Jenis Kelamin yang Berbeda

Berdasarkan hasil data di lapangan, PUS di Kabupaten Musi Rawas menunjukkan keinginan untuk mendapatkan anak dengan jenis kelamin yang berbeda sehingga mereka tidak ikut serta dalam program KB. Mereka juga sama beranggapan bahwa anak dengan jenis kelamin berbeda akan memberikan karakteristik dan keunikan yang berbeda pula. Bagi mereka, anak laki-laki dapat membantu mereka dalam kegiatan berladang serta membantu melindungi ibu dan saudarasaudara perempuannya. Begitu juga dengan anak perempuan, mereka dapat membantu ibunya untuk memasak, mencuci pakaian, dan urusan rumah tangga lainnya. Secara psikologis, anak laki-laki dan perempuan memiliki karakteristik yang berbeda-beda pula sehingga dapat melengkapi memenuhi kebutuhan psikologis dalam hidup berumah tangga.

Pada Tabel 1 tampak PUS yang tidak setuju hanya 23,6 persen serta mereka yang setuju dan yakin bahwa mereka tidak menggunakan KB karena alasan ingin mendapatkan anakanak dengan jenis kelamin yang berbeda sebesar 65 persen. Ada di antara mereka yang menginginkan anak laki-laki terlebih dulu dan disusul oleh anak perempuan. Selanjutnya mereka akan merasa tidak cukup dengan sepasang anak saja sehingga menambah sepasang berikutnya. Kepuasaan mempunyai anak dengan jenis kelamin yang berbeda ini merupakan alasan yang telah ada sejak lama.

\section{e. Status Pekerjaan Suami}

Berprofesi sebagai petani mengharuskan mereka meluangkan waktu dari pagi, siang, dan sore untuk berladang setiap harinya. Jika mereka tidak pergi berladang, maka mereka tidak mendapatkan penghasilan untuk keesokan harinya. Bekerja di sektor pertanian mewajibkan mereka selalu merawat ladangnya jika tidak ingin tanamannya layu. Pekerjaan ini menyebabkan para suami tidak 
dapat mengantarkan para istri mengakses KB. Selain itu, pada dasarnya dengan status pekerjaan suami yang sebagian besar sebagai petani, mereka tidak terlalu peduli dengan kesertaannya dalam KB. Data di atas mendeskripsikan bahwa status pekerjaan suami memengaruhi akses KB istri sebesar 60 persen. PUS yang tidak setuju sebanyak 34,5 persen dan 5,5 persen masih ragu dalam memilih alasan ini.

\section{f. Tidak Memahami Pentingnya KB}

Sebagian PUS yang berada di wilayah ini masih tinggal di perdesaan yang notabene masih mengikuti gaya hidup tradisional. Begitu pula dengan pemahaman KB mereka yang masih terbatas. Pemahaman mereka tentang pantang berkala dan sistem kalender tradisional dalam menggunakan KB masih berjalan dengan baik. Dapat disimpulkan bahwa 61,8 persen berpendapat bahwa mereka hanya paham KB sebagai kegiatan untuk menekan jumlah anak, tetapi belum mampu memaknai manfaat KB yang sebenarnya. Sebagaimana diketahui, manfaat KB selain menekan jumlah penduduk adalah mampu meningkatkan kualitas sumber daya manusia, ekonomi, dan kesejahteraan keluarga.

\section{g. Tidak Ada Alat/Cara KB yang Sesuai Keinginan}

PUS yang ada di Kabupaten Musi Rawas juga memiliki permasalahan dalam penggunaan KB. Banyak PUS merasa tidak cocok dengan semua jenis KB yang mereka gunakan, baik yang digunakan oleh Wanita Usia Subur (WUS) maupun untuk pria. Pada penjelasan di atas dapat dikemukakan bahwa terdapat 54,5 persen PUS yang menyetujui pendapat tersebut. Mereka yang tidak menyetujui hanya sebesar 29,1 persen dan yang netral atau ragu-ragu bernilai 16,4 persen.

\section{h. Tidak Ada Kegiatan/Program KB}

PUS di Kabupaten Musi Rawas merasa sosialisasi terkait program KB masih kurang. Ketika dilakukan wawancara secara mendalam, mereka beranggapan bahwa telah ada sosialisasi, tetapi tidak langsung kepada warganya. Wilayah yang luas dan berjauhan serta adanya keterisolasian tempat tinggal menyulitkan mereka mendapatkan sosialisasi. Bukan hanya itu saja, kesibukan berladang membuat mereka juga tidak memiliki waktu untuk mencari informasi tentang KB. Keterbatasan ini membuat mereka tidak menggunakan KB secara benar dan hanya menggunakan yang masih sederhana, yaitu $\mathrm{KB}$ kalender dan sanggama terputus, yang masih tinggi risiko kehamilannya.

Kasus penyebab rendahnya peserta KB aktif ini sebenarnya hanya disebabkan oleh kurang pemerataan sosialisasi, terutama pada PUS yang berada di wilayah-wilayah pelosok. Sebanyak 56,4 persen PUS menyetujui alasan ini sebagai faktor penyebab rendahnya peserta KB aktif. Untuk PUS yang berada dekat pusat kota di kawasan Musi Rawas, mereka tidak menyetujuinya karena mereka merasa telah mendapatkan sosialisasi tentang $\mathrm{KB}$.

Upaya Meningkatkan Keikutsertaan Peserta KB Aktif dalam Rangka Pencapaian Target Renstra BKKBN 2015-2019 di Kabupaten Musi Rawas Provinsi Sumatera Selatan

Berdasarkan hasil penelitian ini, diketahui bahwa rendahnya peserta KB aktif di Kabupaten Musi Rawas Provinsi Sumatera Selatan disebabkan oleh banyak faktor. 
Hasil penelitian ini mendukung teori Bulatao (Adioetomo dan Samosir, 2011: 192) yang mengatakan adanya faktor-faktor penentu KB. Alasan-alasan tersebut adalah jumlah anak lebih daripada dua, pemahaman bahwa banyak anak banyak rezeki, khawatir merasa kesepian, masih berkeinginan mendapat anak dengan jenis kelamin yang berbeda, usia suami yang masih muda, usia istri yang masih muda, usia pernikahan yang masih muda, status pekerjaan suami, tidak memahami pentingnya $\mathrm{KB}$, tidak ada alat/cara $\mathrm{KB}$ yang sesuai keinginan, dan tidak ada kegiatan/ program KB.

Upaya meningkatkan keikutsertaan peserta KB Aktif dalam rangka pencapaian target Renstra BKKBN 2015-2019 di Kabupaten Musi Rawas, Provinsi Sumatera Selatan dapat diuraikan sebagai berikut.

Pertama, perlu adanya bantuan dana untuk menjangkau wilayah yang terlampau jauh karena wilayah inilah yang rawan fertilitas dengan tingkat kesehatan yang rendah. Selain itu, diperlukan juga penambahan petugas pelayanan KB yang berasal dari tiap wilayah yang ada dan memiliki kedekatan hubungan emosional dengan PUS. Dengan demikian, ketika PUS datang ke tempat pelayanan, mereka merasa nyaman dan lebih terbuka membicarakan alat KB yang mereka inginkan.

Kedua, pada sisi lain pemerintah juga memberikan pelatihan khusus terhadap petugas KB untuk menghadapi karakteristik PUS yang unik dan dengan budaya yang masih tertutup. Petugas diharapkan mampu merangkul PUS yang sulit mengambil keputusan untuk ikut serta pada program KB. Hal selanjutnya yang perlu diperhatikan adalah manajemen waktu untuk melakukan sosialisasi. Diharapkan bahwa sosialisasi dapat dilakukan pada waktu yang paling tepat karena PUS di Kabupaten Musi Rawas
Provinsi Sumatera Selatan ini memiliki pekerjaan di sektor pertanian yang sehariharinya mereka menghabiskan waktu di lahan pertanian tempat mereka bekerja.

Ketiga, sosialisasi dan pelatihan tentang alat KB pada PUS terus dikampanyekan, baik secara langsung mendatangi dari rumah ke rumah maupun di acara-acara formal dan semiformal, misalnya dalam kegiatan musyawarah desa dan hajatan warga. Hal ini dilakukan agar sosialisasi dapat berlangsung secara spontan dalam suasana kumpul dan berdiskusi bersama. Kerja sama dengan para pemangku kepentingan yang terkait dengan program KB juga perlu dijalin, seperti pemangku kepentingan yang berasal dari Dinas Kesehatan dan lurah/kadus/kades. Pendekatan tokoh masyakat dapat dijadikan pelopor bagi PUS untuk ikut serta program KB. Pendekatan pada tokoh masyarakat merupakan cara yang terbaik agar PUS mendapatkan keyakinan dan kepercayaan akan hadirnya hubungan emosional di antara mereka.

Keempat, diberikan bantuan alat kontrasepsi secara gratis. Sebaiknya pemasangan dan bantuan alat kontrasepsi di pos-pos tertentu maupun datang secara langsung ke rumah-rumah. Khususnya pada PUS yang berada di kabupaten yang memiliki keadaan ekonomi yang rendah, sebaiknya diberikan alat dan pemasangan alat KB secara gratis. Hal ini juga tidak menutup kemungkinan juga terjadi di wilayah pelosok Kabupaten Musi Rawas, Provinsi Sumatera Selatan demi tercapainya Target Renstra BKKBN 2015-2019.

Kelima, pengguna KB perlu diberikan apresiasi agar dapat terus mengalami peningkatan. Bentuk apresiasi dapat berupa perlombaan bagi kampung-kampung atau desa yang memiliki PUS terbanyak yang menggunakan KB. Pemenangnya akan 
diberikan hadiah berbentuk barang atau santunan bantuan pendidikan bagi salah satu anak dari lingkungan mereka. Hal yang sama terjadi di Peru. Menurut Gribble, dkk. (2007: 179), dalam merumuskan kebijakan, perlu diperhatikan bahwa perempuan Peru yang tidak mampu merupakan masyarakat yang miskin dan sangat rentan memiliki jumlah anak yang banyak jika tidak segera diantisipasi. Dari hasil penelitiannya, dikatakan bahwa perempuan yang ekonominya tinggi akan lebih optimal menggunakan program Keluarga Berencana. Oleh karena itu, program KB harus terjangkau oleh orang miskin karena dari sisi ekonomi, mereka tergolong masyarakat dengan ekonomi yang rendah.

Pada kegiatan akhir dilakukan monitoring dan evaluasi untuk melihat hambatan dan kekurangan yang memengaruhi proses berjalannya program KB. Selain itu, perlu dilakukan umpan balik serta tinjauan kembali dari hasil monitoring dan evaluasi agar dapat diperbaiki pada program KB berikutnya demi tercapainya target Renstra BKKBN 20152019.

\section{Kesimpulan}

Berdasarkan hasil penelitian di atas, dapat disimpulkan bahwa terdapat beberapa penyebab rendahnya peserta KB aktif di wilayah Kabupaten Musi Rawas. Berikut ini adalah delapan alasan yang menyebabkan ketidakikutsertaan PUS sebagai peserta KB aktif. Pertama adalah jumlah anak lebih daripada dua. Kedua adalah adanya pemahaman bahwa banyak anak banyak rezeki. Ketiga adalah adanya kekhawatiran akan merasa kesepian jika memiliki sedikit anak. Keempat adalah masih adanya keinginan mendapatkan anak dengan kelamin yang berbeda. Kelima adalah status pekerjaan suami. Keenam adalah tidak memahami pentingnya program KB. Ketujuh adalah tidak ada alat/cara KB yang sesuai dengan keinginan. Kedelapan adalah tidak ada kegiatan/program KB yang di wilayah tersebut.

Upaya meningkatkan keikutsertaan peserta KB aktif dalam rangka pencapaian target Renstra BKKBN 2015-2019 di Kabupaten Musi Rawas, Provinsi Sumatera Selatan dapat diuraikan sebagai berikut. Pertama, diperlukan adanya bantuan dana untuk menjangkau wilayah yang terlampau jauh. Kedua, menambah jumlah petugas pelayanan $\mathrm{KB}$ dan memberikan pelatihan khusus pada petugas KB. Ketiga, mengampanyekan sosialisasi dan pelatihan alat KB pada PUS melalui kerja sama dengan para pemangku kepentingan dan tokoh masyakat. Keempat, memberikan bantuan alat dan pemasangan kontrasepsi secara gratis. Kelima, pengguna KB perlu diberikan apresiasi agar dapat terus mengalami peningkatan.

\section{Rekomendasi}

Berdasarkan hasil penelitian ini, maka peneliti merekomendasikan rumusan kebijakan untuk meningkatkan keikutsertaan peserta KB aktif dalam rangka pencapaian target Renstra BKKBN 2015-2019 di Kabupaten Musi Rawas Provinsi Sumatera Selatan. Rumusan kebijakan itu dibagi menjadi empat tahap sebagai berikut.

\section{Tahap Pertama}

1. Adanya bantuan dana tambahan untuk menjangkau wilayah pedalaman. Dalam hal ini disarankan kepada pemerintah untuk memberikan dana tambahan agar dapat menjangkau wilayah pedalaman di Kabupaten Musi Rawas, Provinsi Sumatera Selatan.

2. Adanya penambahan petugas 
pelayanan KB. Agar dapat berjalan dengan baik, sebaiknya ada penambahan tugas pelayanan KB yang berasal dari wilayahnya masing-masing dan memiliki kedekatan hubungan emosional. Dengan demikian, ketika PUS datang ke tempat pelayanan, mereka merasa nyaman dan lebih terbuka terkait dengan alat KB yang mereka inginkan.

3. Adanya pelatihan petugas KB untuk menghadapi karakteristik PUS yang berbeda-beda. Petugas KB diberikan pelatihan terlebih dulu untuk menghadapi PUS yang memiliki karakteristik unik dan berasal dari latar belakang budaya yang masih tertutup. Petugas diharapkan mampu merangkul PUS yang sulit menemukan keputusan dalam ikut serta pada program KB.

4. Adanya manajemen waktu dalam bersosialisasi. Adanya pengaturan waktu yang paling tepat untuk mendatangi PUS yang jarang ada di rumah, misalnya dengan mencari waktu yang tepat dan membuat janji terlebih dulu kepada PUS. Berdasarkan hasil penelitian, biasanya mereka hanya memiliki waktu santai pada sore dan malam hari.

\section{Tahap Kedua}

1. Diberikan sosialisasi dan pelatihan alat KB pada PUS. Setelah membuat janji dengan PUS, petugas KB dan menyosialisasikan dan memberi pelatihan tentang tata cara penggunaan $\mathrm{KB}$.

2. Petugas KB dapat ikut serta mengampanyekan penggunaan KB dengan ikut dalam kegiatankegiatan desa, seperti ikut hadir dalam acara musyawarah desa yang telah teragendakan, dan acara hajatan warga yang meminta waktu. Dalam acara-acara itu, mereka akan meminta izin untuk menyampaikan makna KB dan informasi agar warga dapat mengakses KB di tempat-tempat yang telah ada di sekitarnya.

3. Adanya kerja sama dengan para pemangku kepentingan yang terkait dengan programKB. Halitudimaksudkan agar program dapat berjalan sesuai tujuan dan mendapatkan bantuan yang mendukung berjalan program KB tersebut. Para pemangku kepentingan yang dimaksudkan, misalnya, adalah yang berasal dari Dinas Kesehatan dan lurah/kadus/kades.

4. Adanya pendekatan dengan tokoh masyarakat karena tokoh masyakat merupakan elemen penting dalam mempelopori PUS untuk ikut serta dalam program KB. Pendekatan pada tokoh masyarakat merupakan cara yang terbaik agar PUS mendapatkan keyakinan dan percaya kepada program KB.

\section{Tahap Ketiga}

1. Adanya bantuan alat $K B$ gratis, serta pemasangan dan bantuan alat KB di pos-pos tertentu maupun datang secara langsung ke rumah-rumah. Khususnya pada PUS yang berada di kabupaten yang memiliki keadaan ekonomi yang rendah, sebaiknya mereka diberikan alat dan pemasangan alat KB secara gratis.

2. Adanya apreasiasi terhadap pengguna KB. Pentingnya memberikan apresiasi pada pengguna $\mathrm{KB}$ ini agar terjadi peningkatan PUS yang melakukan program KB tersebut. Bentuk apresiasi dapat berupa perlombaan yang 
diadakan di kampung-kampung atau desa yang terbanyak PUS pengguna $\mathrm{KB}$ dengan memberikan hadiah berbentuk barang atau santunan bantuan pendidikan bagi salah satu anak dari lingkungan mereka.

Tahap Keempat

1. Dilakukan monev terhadap setiap kegiatan demi berlangsungnya program dengan lebih baik. Pada proses ini dapat dilihat hal-hal saja yang akan menjadi hambatan dan kekurangan yang dapat memengaruhi proses berjalannya program KB.

2. 2. Adanya umpan balik dan tinjauan kembali dari hasil monitoring dan evaluasi untuk memperbaiki proses program KB yang lebih baik di masa yang akan datang dalam Target Renstra BKKBN 2015-2019.

Tahapan-tahapan dari rumusan kebijakan di atas dapat disederhanakan dalam sebuah permodelan rekaya sosial/ rumusan kebijakan. Adapun permodelan kebijakan upaya meningkatkan keikutsertaan peserta KB aktif dalam rangka pencapaian target renstra $\mathrm{BKKBN}$ 2015-2019 di Kabupaten Musi Rawas, Provinsi Sumatera Selatan adalah sebagai berikut.

\section{Permodelan Kebijakan Upaya Meningkatkan Keikutsertaan Peserta KB Aktif dalam Rangka Pencapaian Target Renstra BKKBN 2015-2019 di Kabupaten Musi Rawas, Provinsi Sumatera Selatan}

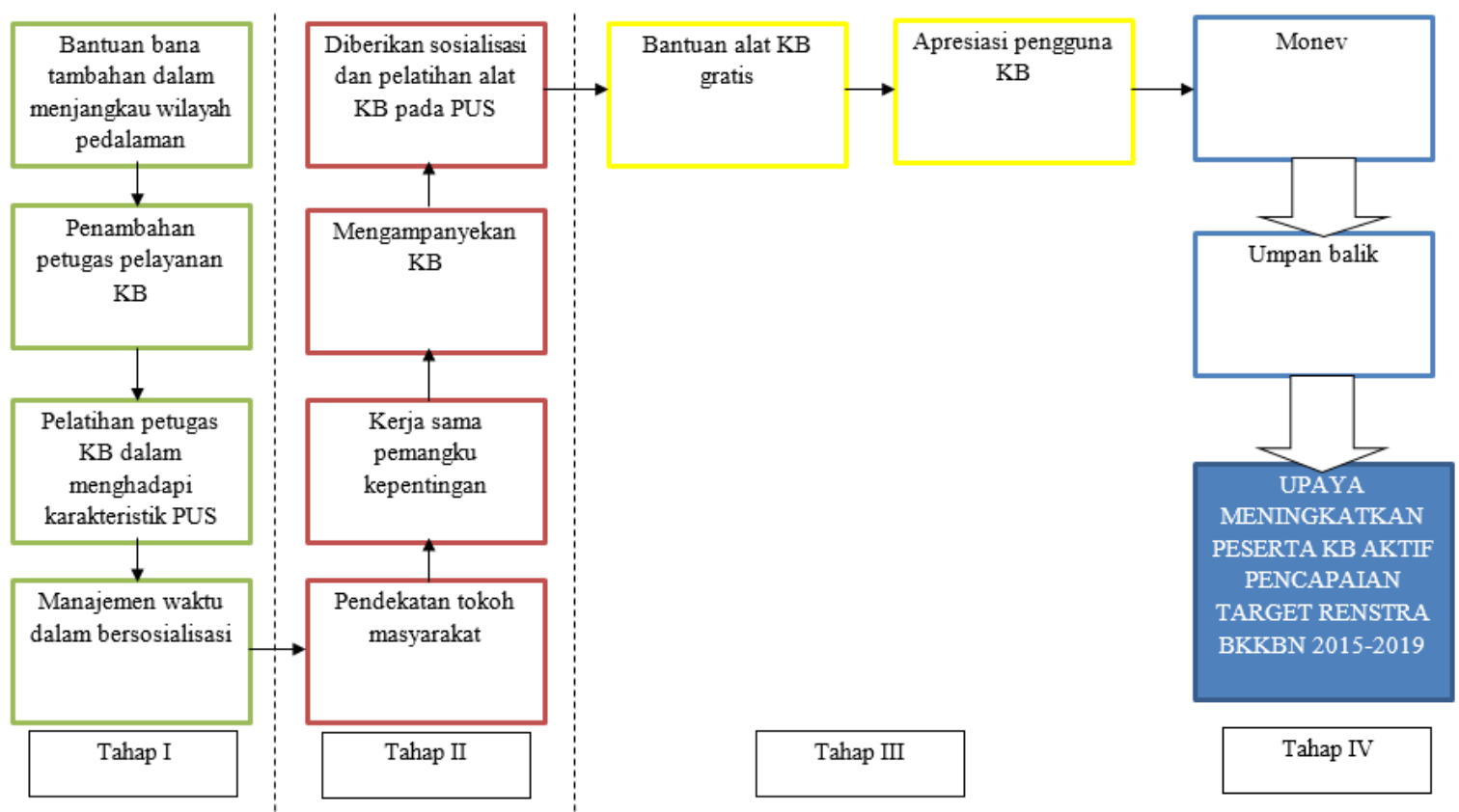




\section{Ucapan Terima Kasih}

Penelitian ini sepenuhnya dibiayai oleh Pusat Puslitbang KB dan KS, BKKBN tahun 2017.

\section{Daftar Pustaka}

Adioetomo, Sri Moertiningsih dan Samosir, Omas Bulan. 2011. Dasar-dasar Demografi. Jakarta Selatan: Salemba Empat.

BKKBN. 2016. Kebijakan Program Kependudukan, Keluarga Berencana, dan Pembangunan Keluarga dalam Mendukung Keluarga Sehat. Jakarta: BKKBN.

BPS Provinsi Sumatera Selatan. 2014.

Statistik Kesejahteraan Rakyat Sumatera

Selatan 2014. Palembang: Badan Pusat

Statistik Provinsi Sumatera Selatan. 2017. Sumatera Selatan Dalam Angka

2017. Palembang: Badan Pusat Statistik Provinsi Sumatera Selatan.

BPS Kabupaten Ogan Komering Ulu Selatan.

2017. Sumatera Selatan Dalam Angka

2017. Palembang: Badan Pusat Statistik

Provinsi Sumatera Selatan.

BPS Kabupaten Musi Rawas. 2017. Sumatera

Selatan Dalam Angka 2017. Palembang: Badan

Pusat Statistik Provinsi Sumatera Selatan.

Gribble, James N. dkk. 2007. "Family Planning

Policies and Their Impacts on the Poor:

Peru's Experience". International Family

Planning Perspectives Journal. Vol.33

No.4. Desember 2007 HIm. 176-181.

Mantra, Ida Bagoes. 2015. Demografi Umum.

Yogyakarta: Pustaka Pelajar.

Saputra, Wahyu and Badrun Munandar. 2017a. "Keputusan Mempunyai Anak Bagi Penduduk Migran Di Pemukiman Kumuh Kota Palembang." Seminar Nasional Kependudukan \& Kebijakan Publik 1(1):82-99. Retrieved (http://conference. unsri.ac.id/index.php/semankkap/article/ view/474/362).
Saputra, Wahyu and Badrun Munandar. 2017b. "Kondisi Pekerjaan Dan Ekonomi Migran Dalam Keputusan Memilih Alat Kontrasepsi Di Pemukiman Kumuh Kota Palembang." Demography Journal of Sriwijaya 5(1):17-23. Retrieved (http:// ejournal-pps.unsri.ac.id/index.php/dejos/ article/view/27/21).

Soebyakto, Bambang Bemby and Wahyu Saputra. 2015. "Influencing Factors of Migrant and Non Migrant Male Worker Income in Informal Sectors: Emprical Study in Kuto Batu Village Ilir Timur District Palembang City." International Journal of Contemporary Applied Sciences 2(7):57-74. Retrieved (http://eprints.unsri. ac.id/5809/2/influence_factor_of_migrant and_non_migrant_male_worker_income_ in_formal.pdf).

Soebyakto, Bambang Bemby, Sukmaniar, and Wahyu Saputra. 2016. "Actualization Social Migration and Intensity of Education: A Case Study in Developed and Developing Countries." Proceeding Sriwijaya Economic and Business Conference 2016 692-98. Retrieved (http://eprints.unsri. ac.id/7095/2/064_SEABC_Bambang_ Bemby_Soebyakto.pdf).

Sukmaniar, Moch Edward Romli, and Devi Novita Sari. 2017. "Faktor Pendorong dan Penarik Migrasi pada Mahasiswa dari Desa untuk Kuliah di Kota Palembang." Demography Journal of Sriwijaya 5(1):110. Retrieved (http://ejournal-pps.unsri. ac.id/index.php/dejos/article/view/25/19).

Tarmizi, Nurlina. 2013. TriMatraKependudukan. Palembang: Universitas Sriwijaya Press.

Yeatman, Sara E. dkk. 2008. "Beyond denomination: The relationship between religion and family planning in rural Malawi". Demographic Research Journal Vol.19 No.55. 24 Oktober 2008. 